\title{
Kemampuan siswa menyelesaikan masalah berbentuk soal cerita sistem persamaan linear ditinjau dari kemampuan penalaran
}

\author{
Dimas Aditya Yudha Pradana ${ }^{1 *}$ (iD), Budi Murtiyasa ${ }^{1}$ \\ ${ }^{1}$ Program Studi Pendidikan Matematika, Universitas Muhammadiyah Surakarta, Surakarta, Indonesia \\ * Corresponding Author. E-mail: adityudha12@gmail.com
}

\begin{tabular}{|c|c|}
\hline ARTICLE INFO & ABSTRACT \\
\hline $\begin{array}{l}\text { Article History: } \\
\text { Received: } 31 \text { Oct. } 2020 \\
\text { Revised: } 21 \text { Dec. } 2020 \\
\text { Accepted: } 29 \text { Dec. } 2020 \\
\text { Keywords: } \\
\text { Pemecahan masalah, } \\
\text { Penalaran matematis, } \\
\text { Persamaan linear dua } \\
\text { variabel, } \\
\text { Soal cerita matematika, } \\
\text { Mathematical reasoning. }\end{array}$ & $\begin{array}{l}\text { Tujuan penelitian ini adalah mendeskripsikan kemampuan pemecahan masalah siswa dalam } \\
\text { menyelesaikan soal cerita sistem persamaan linear dua variabel ditinjau dari kemampuan } \\
\text { penalaran matematis. Penelitian ini merupakan penelitian kualitatif dengan metode deskriptif. } \\
\text { Subjek dalam penelitian adalah siswa kelas VIII C SMP Muhammadiyah } 10 \text { Surakarta tahun } \\
\text { 2019/2020. Teknik pengambilan subjek berdasarkan tingkat kemampuan penalaran matematis } \\
\text { siswa sehingga diperoleh tiga subjek kelas VIII C dengan kategori penalaran matematis rendah, } \\
\text { sedang, dan tinggi. Teknik pengumpulan data berupa hasil tes, wawancara, dan dokumentasi. } \\
\text { Teknik analisis data menggunakan reduksi data, penyajian data dan penarikan kesimpulan. Hasil } \\
\text { penelitian menunjukkan bahwa: (1) siswa dengan penalaran matematis rendah belum dapat } \\
\text { menentukan syarat cukup dan syarat perlu dalam memahami masalah, belum dapat menen- } \\
\text { tukan strategi penyelesaian masalah, belum dapat melaksanakan rencana dan belum dapat } \\
\text { memeriksa perhitungan jawaban; (2) siswa dengan penalaran matematis sedang mampu me- } \\
\text { nentukan syarat cukup dan syarat perlu dalam memahami masalah dan dapat menentukan } \\
\text { strategi penyelesaian masalah, namun belum dapat melaksanakan rencana dan memeriksa per- } \\
\text { hitungan jawaban; (3) siswa dengan penalaran matematis tinggi mampu menentukan syarat } \\
\text { cukup dan syarat perlu dalam memahami masalah, mampu menentukan strategi penyelesaian } \\
\text { masalah, dapat melaksanakan rencana, dan dapat memeriksa perhitungan jawaban; dan (4) } \\
\text { penyebab kesalahan siswa yaitu siswa tidak menuliskan semua informasi, tidak melakukan pe- } \\
\text { misalan, dan menuliskan proses pemecahan masalah secara tidak sistematis. }\end{array}$ \\
\hline
\end{tabular}

Scan me:

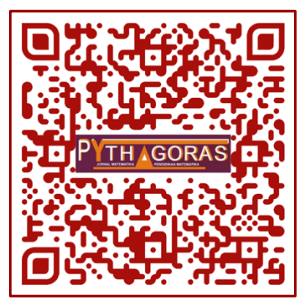

This study aimed to describe the students' ability to solve word problems of a linear equation system in two variables in terms of mathematical reasoning skills. This study was qualitative research with descriptive methods. The subjects were eight graders of a private junior high school, namely SMP Muhammadiyah 10 Surakarta, in 2019/2020. The subjects were three students chosen based on the level of mathematical reasoning skills, namely low, medium, and high. The data collection techniques in the form of test results, interviews, and documentation. Data analysis techniques used data reduction, data presentation, and concluding. The results indicated that: (1) the student with low mathematical reasoning was unable to understand problems, unable to determine problem-solving strategies, unable to implement plans, and unable to lookingback the solution; (2) the student with moderate mathematical reasoning was able to understand problems and determine problem-solving strategies, but unable to carry out plans and looking back the solution yet; (3) the student with high mathematical reasoning was able to understand problems, determine problem-solving strategies, carry out plans, and looking back at the solution; and (4) the causes of student errors, namely students did not write down all important information in the problems, did not make supposition, and wrote problem-solving process unsystematically.

This is an open access article under the CC-BY-SA license

\begin{abstract}
How to Cite:
Pradana, D. A. Y., \& Murtiyasa, B. (2020). Kemampuan siswa menyelesaikan masalah berbentuk soal cerita sistem persamaan linear ditinjau dari kemampuan penalaran. Pythagoras: Jurnal Pendidikan Matematika, 15(2), $151-164$. https://doi.org/10.21831/pg.v15i2.35419
\end{abstract}




\section{PENDAHULUAN}

Pendidikan merupakan proses pembelajaran untuk mengembangkan potensi setiap individu dengan harapan memiliki upaya untuk menghadapi tantangan dan menyelesaikan masalah, sehingga mampu beradaptasi dengan perkembangan zaman. Saragih dan Napitupulu (2015) menyatakan bahwa pendidikan dapat berperan dalam menentukan kualitas suatu bangsa. Peran pendidikan yang utama adalah memfasilitasi siswa dalam mengembangkan kemampuan, membentuk karakter, memberikan penilaian, membuat suatu keputusan dalam menyelesaikan suatu permasalahan, dan sebagainya. Menurut Kencanawati et al. (2020), pendidikan melalui proses pembelajaran yang baik diharapkan dapat menciptakan sumber daya manusia yang berani bersaing, unggul, dan berkualitas. Pendidikan yang didapatkan siswa mencakup beraneka ragam pelajaran, yang mana salah satu pelajaran yang dapat mengembangkan kemampuan siswa adalah matematika.

Belajar matematika memberikan manfaat kepada siswa dalam mengembangkan kemampuan menalar, berpikir logis dan kritis, menganalisis permasalahan, serta menyelesaikan permasalahan secara sistematis dan kreatif (Hasibuan et al., 2019). Lebih lanjut, Hasibuan et al. (2019) juga mengungkapkan bahwa melakukan kegiatan belajar matematika secara berkualitas dalam memahami konsep dapat meningkatkan keterampilan matematika siswa. Hal ini sependapat dengan Phonapichat et al. (2014) yang menyatakan bahwa tujuan dari pembelajaran matematika adalah untuk memotivasi siswa agar dapat mengatasi permasalahan matematika yang dihadapinya. Beberapa kendala yang mungkin dialami siswa belajar matematika adalah cara siswa dalam memahami dan menentukan strategi penyelesaian masalah. Wahyuddin (2017) menyatakan bahwa kurangnya pemahaman dan penguasaan terhadap strategi penyelesaian masalah matematika merupakan beberapa kendala yang dapat menyebabkan siswa mengalami kesulitan dalam menyelesaikan masalah matematika. Berdasarkan penelitian Dung dan Bao (2017), kesulitan siswa dalam menyelesaikan masalah matematika disebabkan karena kurangnya pemahaman terhadap masalah yang ada dan kesulitan dalam menyusun rencana pemecahan masalah. Kesulitan-kesulitan yang dialami oleh siswa dalam menyelesaikan masalah matematika pada akhirnya dapat menyebabkan siswa melakukan kesalahan (Rafi \& Retnawati, 2018). Dengan demikian, melalui analisis terhadap kesalahan yang dilakukan oleh siswa dalam menyelesaikan masalah, guru dapat mengidentifikasi letak kesulitan siswa dalam menyelesaikan masalah itu sendiri (Hadi etal., 2018; Rafi \& Retnawati, 2018). Lebih lanjut, melalui analisis terhadap proses pemecahan masalah yang siswa lakukan, guru diharapkan juga akan dapat mengidentifikasi tahapan pengerjaan masalah, menetapkan jenis kesulitan, dan memilih strategi yang sesuai untuk mengatasi kesulitan siswa dalam memecahkan masalah matematika tersebut.

Berdasarkan studi Programme for International Student Assessment (PISA) pada tahun 2018, kemampuan matematika siswa Indonesia mencapai skor 379 , sedangkan rata-rata kemampuan matematika OECD mencapai 487 (OECD, 2019). Hasil tersebut mengalami penurunan sebanyak tujuh poin jika dibandingkan dengan pencapaian pada tahun 2015. Hasil studi PISA tersebut tidak sekadar memaparkan poin dan peringkat capaian siswa dalam membaca, matematika, dan sains, tetapi juga memaparkan hasil studi terkait kepribadian siswa, sistem belajar, lingkungan, sistem mendidik dan sebagainya (Kemendikbud, 2019). Menurut Hasibuan et al. (2019), kelemahan siswa dalam matematika yaitu rendahnya kebiasaan membaca sekaligus berpikir dan usaha untuk memperoleh informasi penting yang dapat membantu mereka dalam menentukan strategi untuk memecahkan masalah dan adanya kecenderungan bahwa siswa tidak mengonstruksi sendiri pengetahuannya sehingga pengetahuan tentang proses pemecahan masalah yang pernah dipelajarinya akan dengan mudah terlupakan.

Pemecahan masalah merupakan tolak ukur dari proses matematis karena dalam pembelajaran matematika siswa difasilitasi untuk menggunakan kemampuan dan pengalamannya untuk menyelesaikan masalah matematika (Siagian et al., 2019). Menurut Mawaddah dan Anisah (2015), kemampuan pemecahan masalah matematika meliputi kemampuan memahami masalah, merumuskan model matematika, menentukan metode pemecahan masalah, menjelaskan proses pemecahan masalah dan solusi yang diperoleh, serta membuktikan kebenaran dari proses dan solusi tersebut. Dalam pembelajaran matematika ada beberapa bentuk masalah matematika yang dapat disajikan oleh guru kepada siswa yang salah satunya adalah masalah berbentuk soal cerita. Masalah berbentuk soal cerita merupakan permasalahan yang dinyatakan dalam kalimat dengan mengilustrasikan kegiatan sehari-hari (Amalia et al., 2018). Siswa perlu mendayagunakan kemampuan membaca untuk menerjemahkan masalah dan kemampuan menalar untuk menganalisis masalah sekaligus menerapkan konsep matematika agar dapat menyelesaikan masalah berbentuk soal cerita tersebut (Wahyuddin \& Ihsan, 2016). 
Kemampuan dalam menyelesaikan masalah matematika melalui proses berpikir yang logis tidak terlepas dari kemampuan penalaran yang dimiliki oleh siswa. Menurut Adianto et al. (2016) proses berpikir yang logis yang ditujukan untuk memperoleh suatu simpulan disebut dengan kemampuan penalaran matematis. Menurut Yusdiana dan Hidayat (2018) penalaran matematis merupakan bagian dari proses berpikir yang bertujuan untuk memperoleh suatu generalisasi dan simpulan yang tepat mengenai suatu gagasan serta keterhubungan antara gagasangagasan tersebut. Kemampuan penalaran matematis siswa dapat diamati salah satunya melalui hasil kerja siswa dalam menyatakan masalah yang berbentuk cerita ke dalam bentuk model matematika. Pendayagunaan penalaran matematis diharapkan dapat membuka jalan bagi siswa untuk dapat menyelesaikan masalah matematika. Hal ini sejalan dengan pendapat Sandy et al. (2019) bahwa untuk mencari solusi alternatif dari suatu masalah, siswa perlu melibatkan pemikiran dan penalaran keterampilan yang dimiliki.

Tahapan dalam menyelesaikan soal cerita dengan prosedur Polya dinilai sederhana dan mampu dipahami dengan mudah oleh siswa. Menurut Abdullah et al. (2010) memecahkan masalah dengan prosedur Polya lebih efektif untuk membangun keterampilan matematika siswa. Hal ini juga disampaikan oleh Lee (2017) bahwa prosedur Polya mampu memberikan siswa petunjuk untuk menemukan jawaban sendiri sehingga membantu siswa dalam belajar secara efektif. Pemecahan masalah berdasarkan prosedur Polya memiliki empat tahap, yaitu memahami masalah, menyusun rencana, melaksanakan rencana, dan memeriksa kembali jawaban (Polya, 1973). Tahapan penyelesaian masalah berdasarkan prosedur Polya tersebut kemudian dijadikan sebagai rujukan dalam melakukan analisis terhadap kemampuan siswa dalam menyelesaikan masalah matematika dalam penelitian ini.

Kemampuan menyelesaikan masalah berbentuk soal cerita hendaknya perlu dilakukan karena berkaitan dengan kehidupan sehari-hari siswa. Salah satu materi matematika yang sering melibatkan masalah berbentuk soal cerita yang berkaitan pada masalah sehari-hari adalah materi sistem persamaan linear. Dibutuhkan kemampuan penalaran matematis yang baik agar mampu memahami soal dan membuat model matematika dari masalah matematika berbentuk soal cerita tersebut. Beberapa penelitian terdahulu telah dilakukan untuk mendeskripsikan kemampuan atau kesalahan siswa dalam menyelesaikan masalah yang berbentuk soal cerita sistem persamaan linear (misalnya, Amalia et al., 2018; Azzahra \& Pujiastuti, 2020; Lineaus et al., 2016; Pradini, 2019; Rahayuningsih \& Qohar, 2014). Akan tetapi, penelitian tersebut belum memperhatikan tingkat kemampuan penalaran matematis siswa. Selain itu, meskipun beberapa penelitian terdahulu sudah menyelidiki keterkaitan antara kemampuan pemecahan masalah dan penalaran matematis siswa, penelitian tersebut lebih berfokus pada pengkajian terhadap penalaran matematis ditinjau dari kemampuan pemecahan masalah (misalnya, Hidayatullah et al., 2019). Oleh karena itu, penelitian ini lebih difokuskan pada usaha untuk mengeksplorasi dan kemudian mendeskripsikan kemampuan siswa dalam menyelesaikan masalah soal cerita sistem persamaan linear berdasarkan kemampuan penalaran matematis.

\section{METODE}

Penelitian ini merupakan penelitian kualitatif dengan metode deskriptif yang dilaksanakan pada 20 November 2019 hingga tanggal 6 Desember 2019 di SMP Muhammadiyah 10 Surakarta tahun pelajaran 2019/2020. Metode deskriptif digunakan dengan tujuan mendeskripsikan kemampuan menyelesaikan masalah berbentuk soal cerita materi sistem persamaan linear dua variabel ditinjau dari kemampuan penalaran matematis. Subjek dalam penelitian ini terdiri atas tiga siswa yang dipilih dari 20 siswa kelas VIII C yang masing-masing mewakili kemampuan penalaran matematis siswa level tinggi, sedang, dan rendah.

Tabel 1. Pedoman penilaian kemampuan penalaran matematis

\begin{tabular}{|c|c|}
\hline Skor & Keterangan \\
\hline 4 & $\begin{array}{l}\text { Menggunakan ide, prosedur dan jawaban secara benar dan tepat, siswa menggunakan pengetahuan } \\
\text { dari bahasa pengukuran, aljabar, geometri dan bilangan }\end{array}$ \\
\hline 3 & $\begin{array}{l}\text { Menggunakan ide, prosedur dan jawaban secara benar, penjelasan lebih baik tetapi mengandalkan } \\
\text { pada pengetahuan konkret atau visual dari pengetahuan abstrak }\end{array}$ \\
\hline 2 & Menggunakan ide dan prosedur sebagian benar dan penalarannya tidak lengkap atau jelas \\
\hline 1 & Menggunakan ide dan prosedur sangat minim, tapi beberapa alasan dicoba mengemukakan. \\
\hline 0 & $\begin{array}{l}\text { Tidak menggunakan ide dan prosedur sama sekali dan tidak menggunakan istilah-istilah dalam bahasa } \\
\text { pengukuran, data dan peluang, aljabar, geometri, dan bilangan }\end{array}$ \\
\hline
\end{tabular}


Penelitian ini diawali dengan melibatkan 20 siswa yang diberikan soal tes penalaran matematis yang terdiri atas empat butir soal berbentuk soal cerita materi sistem persamaan linear dua variabel dengan alokasi waktu pengerjaan soal tes selama 60 menit. Pemberian skor terhadap jawaban siswa untuk setiap butir soal didasarkan pada aspek kemampuan penalaran matematis, yaitu mengajukan dugaan, melakukan manipulasi, menyusun bukti, dan memberikan alasan atau bukti terhadap solusi. Selanjutnya, jumlah dari keseluruhan skor setiap aspek dihitung untuk mengategorikan kemampuan penalaran matematis ke dalam tiga kategori, yaitu rendah, sedang, dan tinggi. Tabel 1 menunjukkan pedoman penilaian kemampuan penalaran matematis yang dikembangkan oleh Wahyuni et al. (2019, p. 84).

Tabel 1 menunjukkan bahwa skor untuk setiap soal berkisar antara 0 sampai 4. Oleh karena skor maksimal yang dapat dicapai oleh siswa untuk satu butir soal adalah 4 dan banyaknya butir soal pada tes kemampuan penalaran matematis adalah empat, berarti skor maksimal yang dapat dicapai oleh siswa pada tes tersebut adalah 16. Dari skor kemampuan penalaran matematis pada rentang 0 sampai dengan 16 tersebut kemudian dibuat tiga kategori kemampuan penalaran matematis, yaitu kategori rendah, sedang, dan tinggi (lihat Tabel 2).

Tabel 2. Kategori kemampuan penalaran matematis siswa

\begin{tabular}{ll}
\hline Skor & Kategori \\
\hline$N>9$ & Tinggi \\
$3<N \leq 9$ & Sedang \\
$N \leq 3$ & Rendah
\end{tabular}

Berdasarkan hasil tes kemampuan penalaran matematis pada 20 siswa, diperoleh sebanyak 1 (5\%) siswa memiliki kemampuan penalaran matematis pada kategori tinggi, 16 (80\%) siswa memiliki kemampuan penalaran matematis pada kategori sedang, dan $3(15 \%)$ siswa memiliki kemampuan penalaran matematis pada kategori rendah. Dari 20 siswa tersebut, kemudian dipilih tiga siswa untuk dijadikan sebagai subjek penelitian. Pemilihan subjek menggunakan pertimbangan bahwa mereka memiliki jawaban yang sesuai dengan aspek penyelesaian masalah. Pemilihan subjek ini merupakan bagian dari mereduksi data yang menunjukkan kegiatan merangkum, memilih hal-hal pokok, memfokuskan hal-hal penting, menentukan tema dan pola, serta membuang data yang dianggap tidak perlu (Sutama, 2019). Pekerjaan tiga siswa pada tes penalaran matematis tersebut kemudian dianalisis lebih lanjut untuk mendeskripsikan kemampuan pemecahan masalah berbentuk soal cerita sistem persamaan linear ditinjau dari kemampuan penalaran.

Tabel 3. Pedoman penilaian kemampuan menyelesaikan masalah

\begin{tabular}{|c|c|c|}
\hline Aspek & Kategori & Deskripsi \\
\hline \multirow[t]{3}{*}{$\begin{array}{l}\text { Memahami } \\
\text { masalah }\end{array}$} & Mampu & $\begin{array}{l}\text { Mengidentifikasi seluruh unsur yang diketahui dan ditanyakan secara } \\
\text { lengkap dan tepat. }\end{array}$ \\
\hline & Kurang mampu & $\begin{array}{l}\text { Mengidentifikasi unsur yang diketahui dan ditanyakan kurang lengkap } \\
\text { atau kurang tepat }\end{array}$ \\
\hline & Tidak mampu & Tidak mengidentifikasi unsur yang diketahui dan ditanyakan \\
\hline \multirow{3}{*}{$\begin{array}{l}\text { Merancang } \\
\text { rencana }\end{array}$} & Mampu & Merancang rencana sesuai dengan masalah yang ditulis secara tepat \\
\hline & Kurang mampu & Merancang rencana tidak sesuai dengan pemecahan masalah \\
\hline & Tidak mampu & Tidak menuliskan rumusan masalah \\
\hline \multirow{3}{*}{$\begin{array}{l}\text { Melaksanakan } \\
\text { rencana }\end{array}$} & Mampu & Melaksanakan seluruh rencana perhitungan dengan tepat \\
\hline & Kurang mampu & Melaksanakan rencana kurang lengkap atau kurang tepat \\
\hline & Tidak mampu & Tidak melaksanakan rencana \\
\hline \multirow[t]{3}{*}{$\begin{array}{l}\text { Mengecek } \\
\text { kembali solusi }\end{array}$} & Mampu & $\begin{array}{l}\text { Menganalisis solusi yang diperoleh serta menyusun kesimpulan dengan } \\
\text { tepat }\end{array}$ \\
\hline & Kurang mampu & $\begin{array}{l}\text { Menganalisis solusi tidak sesuai jawaban atau tidak sesuai prosedur dan } \\
\text { kurang tepat }\end{array}$ \\
\hline & Tidak mampu & Tidak menganalisis solusi yang diperoleh \\
\hline
\end{tabular}

Data kemampuan pemecahan masalah siswa dikumpulkan menggunakan tes, dokumentasi, dan wawancara. Instrumen yang digunakan dalam penelitian ini berupa tes kemampuan penalaran matematis dan pedoman wa- 
wancara. Penilaian yang digunakan untuk mendeskripsikan kemampuan menyelesaikan masalah didasarkan pada pedoman penilaian kemampuan pemecahan masalah yang dimodifikasi dari Chabibah et al. $(2019$, p.201) (lihat Tabel 3). Wawancara dilakukan untuk mengumpulkan informasi tambahan terkait proses pemecahan masalah siswa pada tes yang telah siswa kerjakan dan permasalahan yang dihadapi oleh siswa dalam memecahkan masalah pada tes tersebut. Wawancara terhadap subjek penelitian dilakukan pada tanggal 6 Desember 2019. Dokumentasi terdiri dari proses penelitian, foto hasil jawaban siswa, dan transkrip wawancara. Data yang terkumpul kemudian dianalisis menggunakan tahapan berupa reduksi data, penyajian data, dan verifikasi atau penarikan simpulan. Tahap reduksi data dilakukan untuk mereduksi data pekerjaan siswa, lalu menyajikan jawaban dengan melihat langkah-langkah pemecahan masalah. Tahap reduksi data melibatkan dua orang ahli di bidang matematika, yaitu satu guru matematika kelas VIII SMP Muhammadiyah 10 Surakarta dan satu dosen dari Program Studi Pendidikan Matematika Universitas Muhammadiyah Surakarta. Tahap penyajian data dilakukan untuk menampilkan hasil pekerjaan siswa yang merefleksikan kemampuan menyelesaikan masalah siswa dan transkrip wawancara yang mungkin merefleksikan kesulitan atau masalah yang dialami oleh siswa dalam memecahkan masalah sehingga dapat ditarik suatu simpulan.

\section{HASIL PENELITIAN}

\section{Kemampuan Siswa dengan Penalaran Matematis Tinggi dalam Menyelesaikan Masalah}

Berdasarkan jawaban dari siswa penalaran matematis tinggi menurut Gambar 1, siswa yang penalaran matematisnya berada pada kategori tinggi sudah mampu memahami masalah yang ditunjukkan oleh bukti bahwa siswa sudah menuliskan langkah diketahui dan ditanyakan dengan menuliskan semua informasi terkait soal dan mengidentifikasi masalah. Siswa tersebut juga sudah mampu merencanakan penyelesaian masalah dengan melakukan pemisalan dan menyederhanakan persamaan agar koefisien pada persamaan tersebut tidak berbentuk pecahan dengan tujuan untuk mempermudah perhitungan. Selanjutnya, siswa sudah mampu melaksanakan rencana penyelesaian masalah yang telah ditetapkannya dengan cara menuliskan proses secara sistematis untuk memperoleh hasil dengan melakukan eliminasi terhadap persamaan pertama dan kedua, sehingga mampu memperoleh hasil dengan tepat. Akan tetapi, siswa tersebut kurang mampu mengecek kembali jawaban yang diperoleh. Lebih lanjut, meskipun sebenarnya siswa mampu menjelaskan proses penyelesaian masalah secara sistematis, namun cara siswa membaca soal dan mengecek setiap langkah belum sesuai dengan aspek menyelesaikan masalah.

Hasil analisis terhadap kemampuan siswa dengan penalaran matematis tinggi dalam menyelesaikan masalah yang didasarkan pada jawaban siswa (lihat Gambar 1) kemudian dikonfirmasi melalui wawancara. Berikut disajikan transkrip hasil wawancara peneliti $(\mathrm{P})$ dengan siswa dengan penalaran matematis tinggi $(\mathrm{T})$ dalam menyelesaikan soal nomor 2, yaitu "Setengah uang Adit ditambah 2/3 uang Ridwan adalah Rp22.000,00. Sedangkan 2/5 uang Adit ditambah 1/2 uang Ridwan adalah Rp17.000,00. Tentukan besar masing-masing uang Adit dan Ridwan."

P: "Perhatikan soal nomor 2, dari soal yang kamu baca apa saja yang diketahui dalam soal?"

$\mathrm{T}$ : "Setengah uang Adit ditambah $\frac{2}{3}$ uang Ridwan adalah Rp22.000,00. Sedangkan $\frac{2}{5}$ uang Adit ditambah $\frac{1}{2}$ uang Ridwan adalah Rp17.000,00"

$P$ : “Apa yang ditanyakan?"

$\mathrm{T}$ : "Besar masing-masing uang Adit dan Ridwan"

$\mathrm{P}$ : “Bagaimana kamu merencanakan pemecahan masalah nomor 2?"

$\mathrm{T}$ : "Memisalkan uang Adit $=x$ dan uang Ridwan $=y$ "

$\mathrm{P}$ : "Bagaimana kamu menyelesaikan rencana soal nomor 2 ?"

T: "Menuliskan persamaan $\frac{1}{2} x+\frac{2}{3} y=22000$ persamaan pertama dan $\frac{2}{5} x+\frac{1}{2} y=17000$ sebagai persamaan kedua"

P: "Bagaimana caramu menentukan nilai $x$ dan $y$ itu?"

$\mathrm{T}$ : "Mengalikan penyebut masing-masing persamaan supaya bentuknya tidak pecahan, yang persamaan pertama dikalikan 6 terus yang persamaan kedua dikalikan $10^{\prime \prime}$

$\mathrm{P}$ : "Jadi bagaimana bentuk persamaannya setelah dikalikan?"

$T:$ : $3 x+4 y=132000$ untuk persamaan pertama, $4 x+5 y=170000$ untuk persamaan kedua"

$P$ : “Kenapa persamaan pertama dikalikan 4 dan persamaan kedua dikalikan 3?”

$\mathrm{T}$ : "Untuk menyamakan nilai $x$ Pak, supaya nanti ketemu nilai $y$ "

$P$ : "Bagaimana bentuk persamaannya?" 
$\mathrm{T}$ : “Persamaan pertama menjadi $12 x+16 y=528000$, persamaan kedua menjadi $12 x+15 y=510000$ ”

$P$ : "Bagaimana memperoleh nilai $y$ ?"

$\mathrm{T}$ : “Dengan mengurangkan persamaan pertama dan kedua, nilai y nya ketemu 18000"

$\mathrm{P}$ : "Bagaimana memperoleh nilai $x$ ?"

$\mathrm{T}$ : “Nilai $y$ nya adalah 18000 lalu disubstitusikan ke persamaan pertama, sehingga nilai $x$ nya ketemu 20000 "

P : "Jadi apa kesimpulannya?"

T: “Jadi uang Adit 20000, uang Adit 18000"

P: “Apakah kamu sudah mengecek kembali jawaban nomor 2?"

T: "Sudah"

$P$ : "Bagaimana caramu mengecek jawaban?"

T: "Membaca soal dan mengecek langkah-langkahnya”

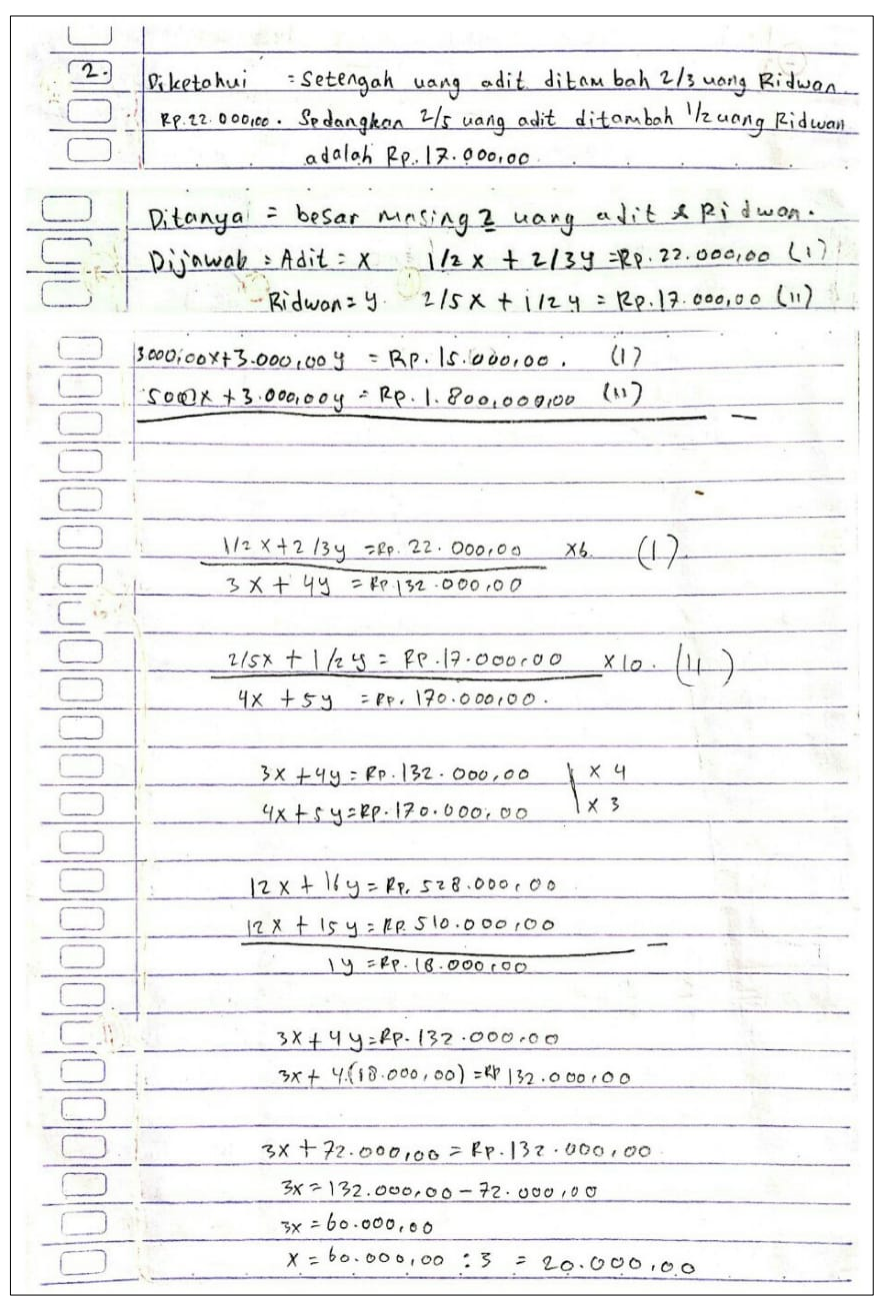

Gambar 1. Hasil pekerjaan siswa penalaran matematis tinggi dalam menyelesaikan soal nomor 2

Berdasarkan hasil tes dan wawancara, pada tahap memahami masalah siswa dengan penalaran matematis tinggi sudah mampu memahami permasalahan di semua soal dalam tes yang diberikan dengan menuliskan semua informasi yang diketahui dan mampu mengidentifikasi masalah yang ada. Pada tahap merencanakan penyelesaian masalah siswa mampu menyusun rencana untuk menyelesaikan masalah pada soal nomor 1a, 1b, 1c, 2, dan 4 dengan melakukan pemisalan, sedangkan pada nomor 3, siswa mengalami kesalahan pada langkah awal berupa tidak melakukan pemisalan dan merasa kesulitan untuk menyusun metode atau rencana penyelesaian masalah. Pada tahap melaksanakan rencana pemecahan masalah, siswa mampu melaksanakan rencana pada penyelesaian masalah pada soal nomor 1a, 1b, 1c, dan 2 dengan membuat persamaan dan memberikan kesimpulan dengan jawaban yang tepat, sedangkan pada nomor 4 mampu membentuk persamaan yang merepresentasikan masalah yang ada namun tidak dapat melaksanakan rencana yang telah disusunnya dan tidak memberikan kesimpulan dengan jawaban yang tepat. Kemudian, pada nomor 3 , siswa dengan penalaran matematis pada kategori tinggi ini 
tidak mampu menyelesaikan masalah dikarenakan tidak dapat menyusun rencana. Pada tahap mengecek kembali jawaban siswa mampu mengecek kembali jawaban pada nomor $1 \mathrm{a}, 1 \mathrm{~b}$, dan $1 \mathrm{c}$ dengan cara membaca soal dan memeriksa setiap langkah perhitungan, namun pada nomor 2 siswa kurang mampu mengecek jawaban karena cara siswa mengecek jawaban tidak sesuai dengan aspek penyelesaian masalah.

\section{Kemampuan Siswa dengan Penalaran Matematis Sedang dalam Menyelesaikan Masalah}

Berdasarkan jawaban dari siswa dengan penalaran matematis pada kategori sedang sebagaimana disajikan pada Gambar 2, siswa mampu memahami masalah dengan menuliskan langkah yang diketahui dan ditanyakan dengan menuliskan semua informasi terkait soal dan mampu mengidentifikasi masalah yang diberikan. Siswa juga sudah mampu merencanakan penyelesaian masalah dengan melakukan pemisalan dan melakukan manipulasi matematika dengan baik, yaitu melakukan pemisalan dengan menggunakan variabel $x$ dan $y$. Namun demikian, variabel $x$ seharusnya bukan mewakili kelas I, tetapi mewakili banyaknya karcis pertunjukan pentas seni untuk kelas I yang terjual dan $y$ bukan mewakili kelas II, tetapi mewakili banyaknya karcis pertunjukan pentas seni untuk kelas Il yang terjual. Selanjutnya, siswa kurang mampu melaksanakan rencana. Sebenarnya siswa mampu menjelaskan proses untuk memperoleh hasil penyelesaian masalah dengan melakukan eliminasi terhadap persamaan pertama dan kedua, tetapi siswa tidak mampu menyelesaikan rencana tersebut untuk memperoleh hasil yang tepat. Selain itu, siswa tidak mampu mengecek kembali jawaban karena siswa tersebut merasa tidak memiliki cukup waktu untuk menyelesaikan masalah yang ada.

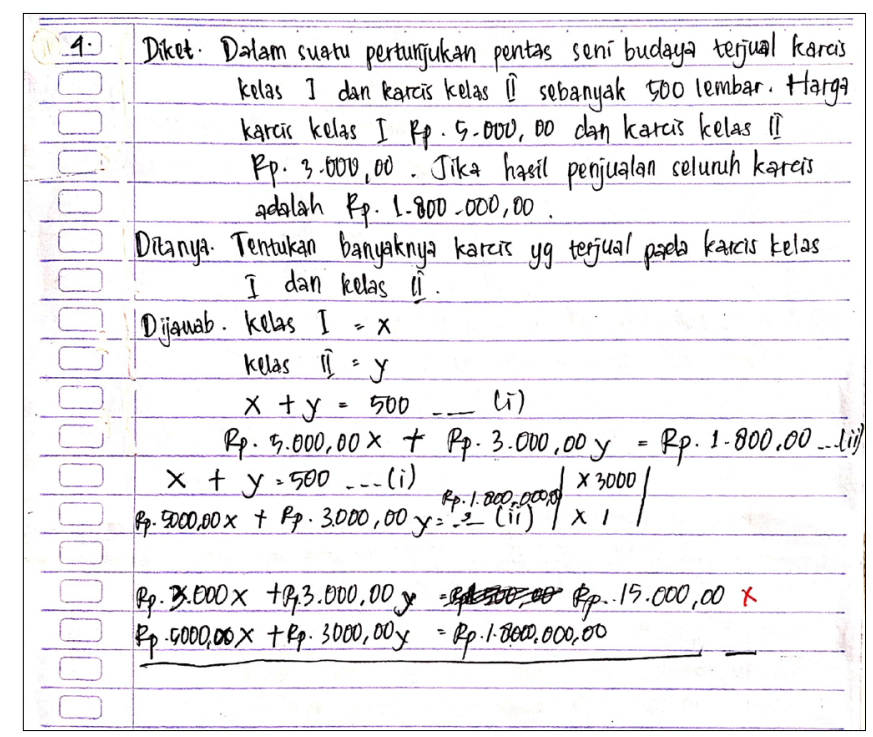

Gambar 2. Hasil pekerjaan siswa penalaran matematis sedang dalam menyelesaikan soal nomor 4

Hasil pekerjaan siswa dalam menyelesaikan masalah pada soal nomor 4, yaitu "Dalam suatu pertunjukkan pentas seni budaya terjual karcis kelas I Rp5.000,00 dan karcis kelas II Rp3.000,00. Jika hasil penjualan seluruh karcis adalah Rp1.800.000,00. Tentukan banyaknya karcis yang terjual pada karcis kelas I dan kelas II." (lihat Gambar 2) selanjutnya dikonfirmasi melalui wawancara. Berikut transkrip wawancara antara peneliti (P) dengan siswa yang memiliki penalaran matematis sedang (S).

P: "Perhatikan soal nomor 4, dari soal yang kamu baca apa saja yang diketahui dalam soal?"

S: "Dalam suatu pertunjukkan pentas seni budaya terjual karcis kelas I dan karcis kelas II sebanyak 500 lembar. Harga karcis kelas I Rp5.000,00 dan karcis kelas II Rp3.000,00. Jika hasil penjualan seluruh karcis adalah Rp1.800.000,00."

$\mathrm{P}$ : “Apa yang ditanyakan?"

S: "Banyaknya karcis yang terjual pada karcis kelas I dan karcis kelas II"

$\mathrm{P}$ : "Bagaimana kamu merencanakan pemecahan masalah nomor 4?"

$S$ : "Memisalkan kelas I $=x$ dan kelas $I=y$ "

$\mathrm{P}$ : "Bagaimana kamu menyelesaikan rencana soal nomor 4?"

S: "Menuliskan persamaan $x+y=500$ untuk persamaan yang pertama terus $5000 x+3000 y=1800000$ untuk persamaan yang kedua" 
$\mathrm{P}$ : "Bagaimana caramu menentukan nilai $x$ dan $y$ itu?"

$\mathrm{S}$ : “Dengan menyamakan nilai $y$ Pak, persamaan pertama saya kalikan 3000 terus persamaan kedua saya kalikan

1. Persamaan pertama menjadi $3000 x+3000 y=15000$ terus persamaan kedua menjadi $5000 x+3000 y=$ 1800000."

P: "Setelah itu?"

$S$ : "Kedua persamaan dikurangi Pak, supaya nanti ketemu nilai $x$ Pak"

P: "Nilai $x$ dan $y$ berapa, kenapa tidak dilanjutkan?”

$S$ : "Waktunya habis Pak"

P: "Apakah kamu sudah mengecek kembali jawaban nomor 4?"

S : "Belum, waktunya habis Pak"

Berdasarkan hasil tes dan wawancara, pada tahap memahami masalah siswa dengan penalaran matematis pada kategori sedang mampu memahami permasalahan di semua nomor dengan menuliskan semua informasi dan mengidentifikasi masalah. Pada tahap merencanakan penyelesaian masalah, siswa sudah mampu menyusun rencana penyelesaian masalah untuk soal nomor 1a, 1b, 1c, 2, dan 4 dengan melakukan pemisalan, sedangkan pada soal nomor 3, siswa mengalami kesalahan pada langkah awal berupa tidak melakukan pemisalan dan merasa kesulitan untuk merencanakan penyelesaian masalah. Pada tahap menyelesaikan rencana siswa hanya mampu menyelesaikan rencana pada soal nomor $1 \mathrm{a}, 1 \mathrm{~b}$, dan $1 \mathrm{c}$ dengan membuat persamaan dan memberikan jawaban dengan tepat, sedangkan pada soal nomor 2 dan 4, siswa sudah mampu membuat persamaan, namun tidak dapat menyelesaikan rencana dan tidak memberikan kesimpulan dengan jawaban yang tepat. Kemudian, pada soal nomor 3, siswa tidak mampu menyelesaikan masalah dikarenakan tidak dapat menyusun rencana penyelesaian untuk masalah yang ada pada soal tersebut. Pada tahap mengecek kembali jawaban, siswa tersebut hanya memeriksa kembali jawaban untuk soal nomor 1a, 1b, dan 1c dengan membaca soal dan memeriksa setiap langkah perhitungan.

\section{Kemampuan Siswa dengan Penalaran Matematis Rendah dalam Menyelesaikan Masalah}

Berdasarkan jawaban dari siswa yang memiliki penalaran matematis pada kategori rendah sebagaimana yang disajikan pada Gambar 3, siswa ini belum mampu memahami masalah. Sebenarnya siswa tersebut sudah mampu menuliskan sebagian informasi yang diketahui dan hal yang ditanyakan, namun belum menuliskan semua informasi penting terkait soal. Siswa tidak melakukan pemisalan dalam merencanakan penyelesaian masalah, namun dalam menyusun rencana siswa hanya membaca informasi dan bernalar dengan menjumlahkan dua bilangan sehingga dalam menyelesaikan rencana siswa memperoleh hasil persamaan yang kurang tepat. Siswa tidak mampu mengecek kembali jawaban karena merasa terburu-buru untuk menyelesaikan masalah.

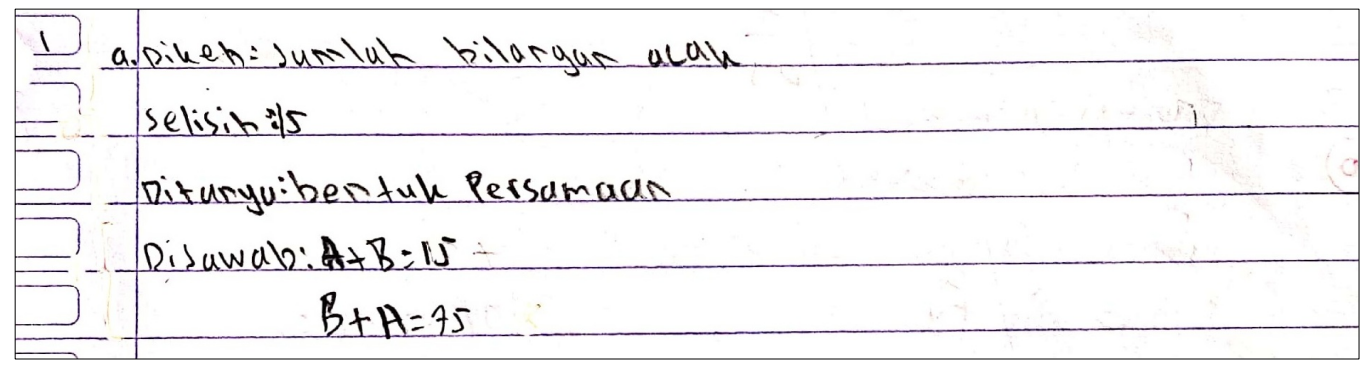

Gambar 3. Hasil pekerjaan siswa penalaran matematis rendah dalam menyelesaikan soal nomor 1a

Setelah melakukan analisis terhadap hasil pekerjaan siswa (lihat Gambar 3), wawancara dilakukan antara peneliti $(P)$ dengan siswa yang memiliki penalaran matematis rendah $(R)$ untuk memperoleh informasi yang lebih lanjut terkait proses penyelesaian masalah pada soal nomor 1a, yaitu "Nyatakan kalimat "Jumlah dua bilangan cacah adalah 75 dan selisih dua bilangan itu adalah 15" dalam bentuk persamaan". Berikut adalah hasil transkrip wawancara yang telah dilakukan.

P: “Perhatikan soal nomor 1a, dari soal yang kamu baca apa saja yang diketahui dalam soal?"

R: "Jumlah bilangan acak dan selisih 15"

$\mathrm{P}$ : “Apa yang ditanyakan?"

$\mathrm{R}$ : "Bentuk persamaan" 
P: "Bagaimana kamu merencanakan pemecahan masalah nomor 1a?"

$\mathrm{R}$ : "Menjumlahkan dua bilangan"

$\mathrm{P}$ : "Bagaimana kamu menyelesaikan rencana nomor 1a?"

$\mathrm{R}$ : "Menuliskan persamaan $A+B=15$ dan $B+A=75$ "

$P$ : “Apakah kamu sudah mengecek kembali jawaban nomor 1a?"

R: "Belum"

P: "Mengapa belum mengecek kembali jawaban nomor 1a?"

R: "Buru-buru Pak"

Berdasarkan hasil tes dan wawancara, pada tahap memahami masalah siswa dengan penalaran matematis rendah hanya mampu memahami permasalahan pada soal nomor $1 \mathrm{~b}$ dengan menuliskan semua informasi yang diketahui dan mengidentifikasi masalah yang ada, sedangkan pada penyelesaian soal nomor 1a, 1c, 2, 3, dan 4, siswa belum menuliskan semua informasi dan belum mengidentifikasi masalah yang ada. Pada tahap merencanakan penyelesaian masalah siswa hanya mampu menyusun rencana untuk soal nomor $1 \mathrm{~b}$ dengan cara melakukan pemisalan, sedangkan pada penyelesaian soal nomor 1a, 1c, 2, 3, dan 4 siswa dengan kategori penalaran rendah ini mengalami kesalahan pada langkah awal berupa tidak melakukan pemisalan dan penulisan penyelesaian masalah secara tidak sistematis. Pada tahap menyelesaikan rencana, siswa hanya mampu menyelesaikan rencana pada soal nomor $1 b$ dengan membuat persamaan, sedangkan pada soal nomor 1a, 1c, 2, 3, dan 4 siswa tersebut tidak membuat persamaan dan tidak dapat memberikan kesimpulan dengan jawaban yang tepat. Pada tahap memeriksa kembali jawaban siswa hanya mengecek kembali jawaban untuk soal nomor $1 \mathrm{~b}$ dengan cara membaca kembali soal dan memeriksa proses perhitungan.

\section{PEMBAHASAN}

Berdasarkan hasil analisis data mengenai kemampuan menyelesaikan masalah berbentuk soal cerita sistem persamaan linear dua variabel, selanjutnya akan dibahas mengenai hasil deskripsi kemampuan menyelesaikan masalah siswa dengan penalaran matematis tinggi, sedang dan rendah berdasarkan aspek tahap penyelesaian masalah.

\section{Kemampuan Siswa dalam Menyelesaikan Masalah pada Tahap Memahami Masalah}

Kemampuan memahami masalah yang berhubungan dengan soal berbentuk cerita merupakan kemampuan siswa menyelesaikan masalah dalam menuliskan informasi dan mengidentifikasi masalah (Amalia et al., 2018). Berdasarkan hasil tes dan wawancara, siswa dengan kategori penalaran matematis tinggi dan sedang mampu memahami permasalahan dengan menuliskan semua informasi dan mengidentifikasi masalah. Hal ini sesuai dengan penelitian Aziza (2019) menunjukkan hasil bahwa dari semua jawaban siswa kategori penalaran matematis tinggi mampu memahami masalah dan menerapkan pengetahuan yang dimiliki dalam memecahkan masalah. Hal serupa ditemukan pada penelitian Listanti dan Mampouw (2020) bahwa siswa berkemampuan matematis sedang mampu memahami masalah dengan menuliskan apa yang diketahui dan ditanyakan. Sedangkan, siswa kategori penalaran matematis rendah tidak memahami masalah dengan tidak menuliskan semua informasi dan mengidentifikasi masalah. Hal ini sesuai dengan penelitian Sandy et al. (2019) bahwa subjek dengan penalaran rendah tidak dapat memenuhi indikator kemampuan penalaran yang diukur. Mereka tidak memahami masalah yang diberikan karena kurangnya pemahaman tentang konsep. Menurut Linola et al. (2017), penyebab siswa tidak mampu menyelesaikan soal cerita adalah siswa belum mengerti apa yang diketahui, apa yang ditanyakan dalam soal cerita dan kesulitan siswa untuk memaknai soal berbentuk cerita.

\section{Kemampuan Siswa dalam Menyelesaikan Masalah pada Tahap Merancang Rencana}

Kemampuan merencanakan penyelesaian masalah yang berhubungan dengan soal berbentuk cerita merupakan kemampuan siswa dalam menyelesaikan masalah dengan cara mengubah kalimat sehari-hari ke dalam kalimat matematika (Amalia et al., 2018). Berdasarkan hasil tes dan wawancara, siswa dengan kategori penalaran matematis tinggi dan sedang mampu merencanakan penyelesaian masalah dengan melakukan pemisalan dan membuat persamaan. Hal ini sesuai dengan penelitian Linola et al. (2017) yang memperoleh hasil bahwa siswa dengan kategori penalaran matematis tinggi mampu merencanakan penyelesaian masalah dengan melakukan manipulasi matematika, menyusun bukti dan memberikan alasan terhadap kebenaran solusi, menarik kesimpulan pernyataan secara logis dengan benar dan tepat. Hasil penelitian ini juga sejalan dengan hasil penelitian yang 
diperoleh Murtiyasa dan Perwita (2020) bahwa siswa dengan kategori penalaran matematis sedang mampu merencanakan penyelesaian masalah dengan cara membentuk model matematika. Siswa dengan kategori penalaran matematis rendah, pada penelitian ini, tidak mampu merencanakan penyelesaian masalah dengan tidak menyusun rencana dan melakukan pemisalan. Siswa yang memiliki penalaran matematis pada kategori rendah mengalami kesalahan pada langkah awal penyelesaian masalah berupa tidak melakukan pemisalan dan penulisan proses penyelesaian masalah yang tidak sistematis. Hasil semacam ini didukung oleh penelitian Wahyuddin (2017) yang menunjukkan bahwa siswa dengan penalaran matematis rendah tidak mampu mengidentifikasi dan menerapkan membuat model matematika atau kurang mampu dalam merencanakan penyelesaian soal berbentuk cerita. Adianto et al. (2016) menyebutkan bahwa dalam menyelesaikan masalah soal berbentuk cerita, kesulitan yang dialami siswa pada tahap merencanakan penyelesaian masalah adalah masih terdapat keraguan dalam menyampaikan ide atau pendapat dalam merencanakan penyelesaian masalah.

\section{Kemampuan Siswa dalam Menyelesaikan Masalah pada Tahap Melaksanakan Rencana}

Kemampuan menyelesaikan atau melaksanakan rencana penyelesaian masalah yang berhubungan dengan soal berbentuk cerita merupakan kemampuan yang berkaitan dengan melakukan operasi perhitungan (Amalia et al., 2018). Berdasarkan hasil tes dan wawancara, siswa dengan kategori penalaran matematis tinggi mampu menyelesaikan rencana dengan membuat persamaan dan memberikan kesimpulan dengan jawaban yang tepat. Hal serupa ditemukan pada penelitian Widodo et al. (2018) bahwa siswa berkemampuan penalaran matematis tinggi mampu menentukan cara dalam menyelesaikan masalah. Selanjutnya, siswa dengan kategori penalaran matematis sedang kurang mampu menyelesaikan rencana penyelesaian masalah dengan membuat beberapa persamaan dan memberikan jawaban yang tidak tepat. Hal ini sejalan dengan penelitian Puspitasari et al. (2018) yang memperoleh hasil bahwa siswa yang memiliki kemampuan penalaran matematis sedang masih mengalami kesulitan dalam menyelesaikan rencana berupa solusi kurang terstruktur, terperinci, dan proses perhitungan kurang sistematis. Kemudian, dalam penelitian ini diperoleh hasil bahwa siswa dengan kategori penalaran matematis rendah tidak mampu menyelesaikan rencana yang ditunjukkan dengan adanya temuan bahwa siswa tersebut tidak membuat persamaan dan tidak dapat memberikan kesimpulan dengan jawaban yang tepat. Phonapichat et al. (2014) mengungkapkan bahwa siswa penalaran matematis rendah tidak dapat memikirkan apa yang harus diasumsikan dan informasi apa yang diberikan pada soal yang berguna untuk menyelesaikan masalah. Menurut Linola et al. (2017), penyelesaian masalah berbentuk soal cerita yang berkaitan dengan kehidupan sehari-hari dapat dicari penyelesaiannya melalui penggunaan kalimat matematika yang memuat operasi hitung bilangan, sehingga siswa mampu untuk menyelesaikan rencana penyelesaian masalah tersebut.

\section{Kemampuan Siswa dalam Menyelesaikan Masalah Siswa pada Tahap Mengecek Kembali Solusi}

Kemampuan mengecek kembali jawaban dalam menyelesaikan masalah yang berhubungan dengan soal berbentuk cerita merupakan kemampuan siswa menyelesaikan masalah dalam menyatakan jawaban akhir sesuai pertanyaan pada soal (Amalia et al., 2018). Siswa kategori penalaran matematis tinggi mampu mengecek kembali jawaban dengan membaca soal dan memeriksa setiap langkah perhitungan. Hal ini sejalan dengan hasil penelitian Listanti dan Mampouw (2020) yang menyimpulkan bahwa siswa kategori kemampuan penalaran matematis tinggi mampu mengecek kembali jawaban dengan memeriksa semua proses perhitungan. Selanjutnya, siswa kategori penalaran matematis sedang kurang mampu mengecek kembali jawaban. Hal ini sesuai dengan penelitian Linola et al. (2017) bahwa siswa kategori penalaran matematis sedang kurang lengkap dalam menyusun bukti dan memberikan alasan terhadap solusi. Kemudian, siswa kategori kemampuan penalaran matematis rendah tidak memeriksa kembali solusi dengan membaca soal dan memeriksa proses perhitungan. Hal ini sesuai dengan penelitian Annizar et al. (2020) mengungkapkan siswa penalaran matematis rendah tidak melakukan pengoreksian kembali baik dalam perhitungan, rumus maupun konsepnya. Menurut Listanti dan Mampouw (2020) penyelesaian masalah berbentuk cerita yang berkaitan dengan mengecek kembali jawaban adalah dengan memasukkan data dan menuliskan langkah-langkah pemecahan masalah sesuai rencana, sehingga dapat memperoleh hasil dan menyimpulkan jawaban akhir yang sesuai.

\section{Implikasi}

Hasil penelitian menunjukkan bahwa menyelesaikan masalah berbentuk soal cerita dipengaruhi oleh kemampuan penalaran matematis yang dimiliki setiap siswa. Wahyuddin dan Ihsan (2016) menyatakan bahwa dalam 
menyelesaikan masalah berbentuk soal cerita, siswa dituntut dapat menguasai kemampuan penalaran matematis yang berguna untuk mengetahui maksud dari permasalahan yang diberikan. Permasalahan berbentuk soal cerita sangat berperan dalam kehidupan sehari-hari siswa karena mengedepankan permasalahan nyata yang berkaitan dengan kehidupan sehari-hari siswa itu sendiri. Namun demikian, penelitian ini menunjukkan bahwa siswa masih mengalami kesulitan dalam menyelesaikan masalah berbentuk soal cerita. Rendahnya kemampuan menyelesaikan masalah berbentuk soal cerita yang berawal dari kesulitan tersebut disebabkan oleh kurangnya keterampilan dan keaktifan siswa dalam proses pembelajaran dalam menyelesaikan masalah (Wahyuddin \& Ihsan, 2016). Peran guru dalam proses pembelajaran sangat diperlukan untuk lebih mengembangkan kemampuan siswa dalam menyelesaikan masalah berbentuk soal cerita. Proses pembelajaran yang diharapkan adalah yang dapat mendorong siswa untuk secara aktif dalam melibatkan penalaran matematis dalam menyelesaikan masalah berbentuk soal cerita, sehingga diharapkan siswa mampu mengemukakan ide atau gagasannya untuk menyelesaikan masalah dan memberikan proses menyelesaikan masalah secara sistematis dan kesimpulan jawaban yang tepat. Selain itu, proses pembelajaran matematika juga diharapkan lebih memfasilitasi siswa untuk membiasakan diri menghadapi masalah berbentuk soal cerita matematika yang mendayagunakan kemampuan pemecahan masalah dan penalaran matematis. Proses pembelajaran yang demikian dapat diciptakan salah satunya melalui penerapan pendekatan matematika realistik, di mana pendekatan ini melibatkan kegiatan eksplorasi terhadap berbagai situasi pada masalah dunia nyata yang diharapkan mampu menyediakan fasilitas bagi siswa untuk dapat menemukan ide dan konsep (Ulandari et al., 2019) serta mendayagunakan penalarannya yang pada akhirnya dapat digunakan untuk menyelesaikan masalah berbentuk soal cerita dengan konteks kehidupan nyata.

\section{SIMPULAN}

Berdasarkan hasil penelitian dan pembahasan, diperoleh empat kesimpulan. Pertama, siswa dengan penalaran matematis sedang dan tinggi mampu memahami masalah, berupa menuliskan semua informasi yang diketahui atau mampu mengidentifikasi masalah yang ada. Siswa dengan penalaran matematis rendah belum menuliskan semua informasi dan mengidentifikasi masalah untuk menyelesaikan masalah. Kedua, siswa dengan penalaran matematis sedang dan tinggi mampu merencanakan penyelesaian masalah dengan melakukan pemisalan. Siswa dengan penalaran matematis rendah belum mampu merencanakan penyelesaian masalah karena mengalami kesalahan pada langkah awal dengan tidak melakukan pemisalan dan penulisan tidak sistematis. Ketiga, siswa dengan penalaran matematis tinggi mampu menyelesaikan rencana dan mampu mendapatkan hasil yang tepat. Adapun siswa dengan penalaran matematis sedang dan rendah belum mampu menyelesaikan rencana untuk mendapatkan hasil yang tepat. Keempat, siswa dengan penalaran matematis tinggi mampu mengecek hasil dengan memeriksa seluruh perhitungan atau menguji solusi yang telah diperoleh. Siswa dengan penalaran rendah dan sedang belum mampu mengecek hasil dengan memeriksa seluruh perhitungan atau menguji solusi. Saran yang dapat disampaikan yaitu siswa hendaknya lebih teliti dalam mengerjakan soal cerita dan perlu melatih, memperdalam materi, dan mempelajari proses pemecahan masalah sehingga mampu memberikan proses secara sistematis dan kesimpulan jawaban yang tepat. Peneliti menyadari penelitian yang dilakukan memiliki batasan pada jumlah soal, cakupan materi tes yang digunakan, dan jumlah siswa yang berpartisipasi dalam penelitian. Oleh karena itu, penelitian yang akan datang diharapkan mampu mengembangkan tes pada materi sistem persamaan linear dua variabel yang membutuhkan kreativitas dan penalaran matematis dalam menyusun strategi penyelesaian masalah sehingga terlihat jelas proses berpikir untuk mendapatkan kesimpulan jawaban yang dikerjakan oleh siswa.

\section{DAFTAR PUSTAKA}

Abdullah, N. I., Tarmizi, R. A., \& Abu, R. (2010). The effects of problem based learning on mathematics performance and affective attributes in learning statistics at form four secondary level. Procedia - Social and Behavioral Sciences, 8, 370-376. https://doi.org/10.1016/j.sbspro.2010.12.052

Adianto, S., Sudia, M., \& Misu, L. (2016). Pengaruh model pembelajaran berbasis masalah terhadap kemampuan penalaran matematis siswa kelas VIII SMP Negeri 4 Kendari. Jurnal Penelitian Pendidikan Matematika, 4(1), 141-154. http://ojs.uho.ac.id/index.php/JPPM/article/view/3058 
Amalia, A., Hirza, B., \& Supriadi, A. (2018). Kemampuan siswa dalam menyelesaikan soal matematika berbentuk cerita pokok bahasan sistem persamaan linear dua variabel. Jurnal Penelitian Pendidikan Matematika, 2(1), 53-62. https://jurnal.um-palembang.ac.id/jpmatematika/article/view/1593

Annizar, A. M., Maulyda, M. A., Khairunnisa, G. F., \& Hijiani, L. (2020). Kemampuan pemecahan masalah matematis siswa dalam menyelesaikan soal PISA pada topik geometri.Jurnal Elemen, 6(1),39-55. https://doi.org/10.29408/jel.v6i1.1688

Aziza, M. (2019). Kemampuan pemecahan masalah siswa dalam menyelesaikan soal tertutup dan terbuka pada pokok bahasan lingkaran. Pythagoras: Jurnal Pendidikan Matematika, 14(2), 126-138. https://doi.org/10.21831/pg.v14i2.26563

Azzahra, R. H., \& Pujiastuti, H. (2020). Analisis kemampuan pemecahan masalah siswa pada materi sistem persamaan linear tiga variabel. Transformasi: Jurnal Pendidikan Matematika dan Matematika, 4(1), 153-362. https://doi.org/10.36526/tr.v4i1.876

Chabibah, L. N., Siswanah, E., \& Tsani, D. F. (2019). Analisis kemampuan pemecahan masalah siswa dalam menyelesaikan soal cerita barisan ditinjau dari adversity quotient. Pythagoras: Jurnal Pendidikan Matematika, 14(2), 199-210. https://doi.org/10.21831/pg.v14i2.29024

Dung, T. M., \& Bao, P. M. (2017). Vietnamese students' problem-solving skills in learning about error of measurements. IEMME: International Electronic Journal of Mathematics Education, 12(3), 463-474. https://www.ejme.com/article/vietnamesestudents-problem-solving-skills-in-learning-about-error-of-measurements

Hadi, S., Retnawati, H., Munadi, S., Apino, E., \& Wulandari, N. F. (2018). The difficulties of high school students in solving higher-order thinking skills problems. Problems of Education in the 21st Century, 76(4), 520-532. https://dx.doi.org/10.33225/pec/18.76.520

Hasibuan, A. M., Saragih, S., \& Amry, Z. (2019). Development of learning materials based on realistic mathematics education to improve problem solving ability and student learning independence. IEJME: International Electronic Journal of Mathematics Education, 14(1), 243-252. https://doi.org/10.29333/iejme/4000

Hasibuan, S. A., Fauzi, K. M. A., \& Mukhtar, M. (2019). Development of PISA mathematical problem model on the content of change and relationship to measure students mathematical problem-solving ability. IEJME: International Electronic Journal of Mathematics Education, 15(2), 1-9. https://doi.org/10.29333/iejme/6274

Hidayatullah, M. S., Sulianto, J., \& Azizah, M. (2019). Analisis kemampuan penalaran ditinjau dari kemampuan pemecahan masalah matematis. Thinking Skills and Creativity Journal, 2(2), 93-102. https://ejournal.undiksha.ac.id/index.php/TSCJ/article/view/21198

Kemendikbud. (2019). Hasil PISA Indonesia 2018: Akses makin meluas, saatnya tingkatkan kualitas. https://www.kemdikbud.go.id/main/blog/2019/12/hasil-pisa-indonesia-2018-akses-makin-meluas-saatnyatingkatkan-kualitas

Kencanawati, S. A. M. M., Sariyasa, S., \& Hartawan, I. G. N. Y. (2020). Pengaruh penerapan model pembelajaran SAVI (somatic, auditory, visual, intellectual) terhadap kemampuan berpikir kreatif matematis. Pythagoras: Jurnal Pendidikan Matematika, 15(1), 13-23. https://doi.org/10.21831/pg.v15i1.33006

Lee, C. I. (2017). An appropriate prompts system based on the Polya method for mathematical problem-solving. Eurasia Journal of Mathematics, Science and Technology Education, 13(3), 893-910. https://doi.org/10.12973/eurasia.2017.00649a

Lineaus, J. F., Rizal, M., \& Anggraini, A. (2016). Analisis pemecahan masalah sistem persamaan linier dua variabel kelas XSMA Negeri 1 Banawa berdasarkan langkah-langkah Polya. Jurnal Elektronik Pendidikan Matematika Tadulako, 3(3), 277-291. http://jurnal.untad.ac.id/jurnal/index.php/JEPMT/article/view/7191

Linola, D. M., Marsitin, R., \& Wulandari, T. C. (2017). Analisis kemampuan penalaran matematis peserta didik dalam menyelesaikan soal cerita di SMAN 6 Malang. Pi: Mathematics Education Journal, 1(1), 27-33. https://doi.org/10.21067/pmej.v1i1.2003 
Listanti, D. R., \& Mampouw, H. L. (2020). Profil pemecahan masalah geometri oleh siswa SMP ditinjau dari perbedaan kemampuan matematika. Jurnal Cendekia: Jurnal Pendidikan Matematika, 4(1), 365-379. https://j-cup.org/index.php/cendekia/article/view/224

Mawaddah, S., \& Anisah, H. (2015). Kemampuan pemecahan masalah matematis siswa pada pembelajaran matematika dengan menggunakan model pembelajaran generatif (generative learning) di SMP. EDU-MAT: Jurnal Pendidikan Matematika, 3(2), 166-175. https://doi.org/10.20527/edumat.v3i2.644

Murtiyasa, B., \& Perwita, W. R. G. (2020). Analysis of mathematics literation ability of students in completing PISAoriented mathematics problems with changes and relationships content. Universal Journal of Educational Research, 8(7), 3160-3172. https://doi.org/10.13189/ujer.2020.080745

OECD. (2019). PISA 2018 results (volume I): What students know and can do. OECD Publishing. https://doi.org/https://doi.org/10.1787/5f07c754-en

Phonapichat, P., Wongwanich, S., \& Sujiva, S. (2014). An analysis of elementary school students' difficulties in mathematical problem solving. Procedia - Social and Behavioral Sciences, 116, 3169-3174. https://doi.org/10.1016/j.sbspro.2014.01.728

Polya, G. (1973). How to solve it: A new aspect of mathematical method. Princeton University Press.

Pradini, W. (2019). Analisis kesalahan siswa dalam menyelesaikan soal cerita persamaan linear dua variabel. Pythagoras: Jurnal Pendidikan Matematika, 14(1), 33-45. https://doi.org/10.21831/pg.v14i1.21481

Puspitasari, L., In'am, A., \& Syaifuddin, M. (2018). Analysis of students' creative thinking in solving arithmetic problems. IEJME: International Electronic Journal of Mathematics Education, 14(1), $49-60$. https://doi.org/10.12973/iejme/3962

Rahayuningsih, P., \& Qohar, A. (2014). Analisis kesalahan menyelesaikan soal cerita sistem persamaan linear dua variabel (SPLDV) dan scaffolding-nya berdasarkan analisis kesalahan Newman pada siswa kelas VIII SMP Negeri 2 Malang. Jurnal Pendidikan Matematika dan Sains, 2(2), 109-116. https://journal.uny.ac.id/index.php/jpms/article/view/7161

Rafi, I., \& Retnawati, H. (2018). What are the common errors made by students in solving logarithm problems? Journal of Physics: Conference Series, 1097(1), 1-9. https://doi.org/10.1088/1742-6596/1097/1/012157

Sandy, W. R., Inganah, S., \& Jamil, A. F. (2019). The analysis of students' mathematical reasoning ability in completing mathematical problems on geometry. MEJ: Mathematics Education Journal, 3(1), 72-79. https://doi.org/10.22219/mej.v3i1.8423

Saragih, S., \& Napitupulu, E. (2015). Developing student-centered learning model to improve high order mathematical thinking ability. International Education Studies, 8(6), 104-112. https://doi.org/10.5539/ies.v8n6p104

Siagian, M. V., Saragih, S., \& Sinaga, B. (2019). Development of learning materials oriented on problem-based learning model to improve students' mathematical problem solving ability and metacognition ability. IEJME: International Electronic Journal of Mathematics Education, 14(2), 331-340. https://doi.org/10.29333/iejme/5717

Sutama, S. (2019). Metode penelitian pendidikan. CV Jasmine.

Ulandari, L., Amry, Z., \& Saragih, S. (2019). Development of learning materials based on realistic mathematics education approach to improve students' mathematical problem solving ability and self-efficacy. IEJME: International Electronic Journal of Mathematics Education, 14(2), 375-383. https://doi.org/10.29333/iejme/5721

Wahyuddin, W. (2017). The Analysis of the problem of economic mathematical problems reversed from the ability of logic thinking in students. IEJME: International Electronic Journal of Mathematics Education, 12(3), 585598. https://www.iejme.com/article/the-analysis-of-the-problem-of-economic-mathematical-problems-reversedfrom-the-ability-of-logic

Wahyuddin, W., \& Ihsan, M. (2016). Analisis kemampuan menyelesaikan soal cerita matematika ditinjau dari kemampuan verbal pada siswa kelas VII SMP Muhammadiyah se-Kota Makassar. Suska Journal of Mathematics Education, 2(2), 111-116. https://doi.org/10.24014/sjme.v2i2.2213 
PYTHAGORAS: Jurnal Pendidikan Matematika, 15 (2), 2020 - 164

Dimas Aditya Yudha Pradana, Budi Murtiyasa

Wahyuni, Z, Roza, Y., \& Maimunah, M. (2019). Analisis kemampuan penalaran matematika siswa kelas X pada materi dimensi tiga. Jurnal IImiah Pendidikan Matematika Al Qalasadi,3(1), 81-92. https://doi.org/10.32505/qalasadi.v3i1.920

Widodo, K., Budiarto, M. T., \& Lukito, A. (2018). Profil pemecahan masalah kreatif siswa MA ditinjau dari tingkat math self-efficacy. JRPIPM: Jurnal Riset Pendidikan dan Inovasi Pembelajaran Matematika, 1(1), 11-18. https://doi.org/10.26740/jrpipm.v1n1.p11-18

Yusdiana, B. I., \& Hidayat, W. (2018). analisis kemampuan penalaran matematis siswa SMA pada materi limit fungsi. JPMI: Jurnal Pembelajaran Matematika Inovatif, 1(3), 409-414. https://doi.org/10.22460/jpmi.v1i3.p409-414 